http://dx.doi.org/10.18778/1508-1117.26.04

Alessandro Vitale

\title{
MYTHS OF TERRITORY AND EXTERNAL BORDERS IN THE EU'S CONTEMPORARY IDEA AND EUROPE IN THE MIDDLE AGES
}

\begin{abstract}
The European spatial development policy discourse has recently taken a "territorial" character, especially after the migrant crisis. Even if the terminology regarding this policy field remains ambiguous, territory, or territoriality, has become de facto an increasingly prevalent notion in the discourse on the organization of "European" (i.e. EU's) space. In fact, the notion of territoriality and the prevalent "territorial" discourse produced an evident eclipse of the widespread notion of "European space" that had been developed in the early 1990s. Basically, the spatial predominant conception of the EU contributes to an emergence of a sharpened territorial building of the European space. The idea of both territorial cohesion and territorial continuity provides relevant insights into the notion of territoriality in the "European discourse" and consequently clearly shows how are accepted the tools of hard bordering (as policies and practices) and the sharp inside/outside dichotomy, typical of a "Westphalian memory" and of an use of territory as support for a unified political unit. Due to this pragmatic notion of territoriality, the idea of the EU as a "non-Westphalian new empire", characterized by softening of borders and sharing of political power across multiple and multilevel politics, became at least unrealistic. On the contrary, Europe has always been distinguished by its openness to the rest of the world. It has never been a clearly demarcated continent or a fixed bordered entity and it has always been characterized by shifting spatialities of politics. The Middle Ages in Europe were characterized by overlapping, divided authority structures and often contentious jurisdictions, without territorial containments and a clear notion of the border. The comprehension of the transnational dimension opens new avenues of research and offers new modes of understanding.
\end{abstract}

Keywords Borders, EU, territoriality, territorial cohesion, Middle Ages. 


\section{Introduction}

Taking into account the interplay between geography and politics, and the possible contribution of historical geography to contemporary policy-making, the issue of EU's external borders and European territoriality seems to be one of the most challenging, controversial and difficult subject of contemporary world. In order to understand this topic, it is possible to use an historical approach which comprises a diachronic comparative method (typical in the methodology of historical geography) incorporating at the same time an interdisciplinary approach that includes research methods of political sciences, history and geography (comparative border studies, territoriality old and new, and so on). As well known, historical geography is distinctively interdisciplinary and actively synthetic. The main problem is that synchronic and diachronic analyses have different pattern of accuracy, are difficult to compare and to examine concurrently. Moreover, it is also difficult to include in the analysis all the historical differences and national particularities, avoiding too wide generalizations and approximate wide-ranging conclusions. Nevertheless, descriptive synthesis remains one of the most relevant tool in this field of research and verstehen plays an important role in some of the most creative investigations in historical geography.

At any rate considering territoriality and borders, the differences between medieval Europe and contemporary post-bipolar Europe are quite evident. The EU has a cultural history that is embedded in a transnational context in which we can find its roots: World War II, and the desire of re-establish trade networks in its wake. Genetically it is based on the idea that a territorially bounded sovereign actor is obsolete and even dangerous (Passerini 2002, p. 200-208). Moreover, the $\mathrm{EU}$ is much more then a new, medium large state that seems to require a prolonged gestation: it is a complex community of states where debate take place continuously, within, between and among national and other entities. Nevertheless, in recent years the European spatial development policy discourse has taken an evident "territorial" character. The spatial predominant conception of the EU (especially the ideas of "territorial cohesion", "territorial governance" and "territorial development policy") contributes to an evident emergence of a modern and sharpened territorial building of the new, fortified "European space" especially after the recent migrant crisis. Despite the fact that terminology regarding this policy field remains ambiguous, territory has become de facto an increasingly prevalent notion in the discourse on the organization of "European" (i.e. EU's) space. The notion of territoriality in the "European discourse" is very relevant and consequently in political theorizing also the tool of hard and closed boundaries and a sharp inside/ outside dichotomy is getting predominant. Already in 1993 the removal of internal borders within the EU and the opening of a common market were accompanied by a continuous strengthening and an increasing importance of external borders. 
Due to this pragmatic and factual notion of territoriality, the current idea of the EU as a "non-Westphalian new empire" reveals itself at least unrealistic. In fact, its boundaries are getting more territorial, physical and visible, in deep contrast with the European historical structures and with the long previous European history. Hard border policies and practices on the borders mirror the existence of a de facto barrier and the permanence of a deep "Westphalian memory" in the way to use the territory as a tool to support a (projected) perfect political unit. While the new Europe would lead to a recognition of cultural diversity and the acceptance of pluralism as the basis for European belonging, the supranational approach taken in the construction of a unified European space mimics the nation-state. Territories and borders are coterminous. Territory suggests a behavioural strategy of boundary making that incorporates a range of political forms and organizations. As Preuss has pointed out, territoriality becomes the basic means of citizenship in Europe (Preuss 1998). However, Europe has always been distinguished by its openness to the rest of the world. It has never been a clearly demarcated continent similar to a great state or a fixed bordered entity and it has always been characterized by shifting spatialities of politics. The multilayered stratification of territorial power is the rule in history. Pre-modern territories were characterized by variety, fluidity, "non-territoriality" in the modern sense of the word, or "nonexclusive" territoriality (Ruggie 1993; Anderson 1996, p. 141). The territorialization of politics has been implied a long term process of the creation of an "internal" and "external" at state borders. It is well known that the Middle Ages in Europe were characterized by overlapping, divided authority structures and often contentious jurisdictions, without territorial containments and a clear notion of the external border. The modern territorial state with its typical territorial idea and the international system developed together. The formation of states with exclusive control of a definite territory owed a great deal to the fact that they were members of an emerging international system that fostered and favoured such political entities. The norms of the system rapidly came to favour coherent territorial entities that had a degree of effective control of the internal space (and the use of violence across their borders). The characteristics of the state were shaped by the international system imposing norms and also because the system selected out this kind of political entities.

Certain of the forces active in the constitution of the state system are not merely historical but are still at work in it. In fact, there is a strong tendency in the modern international system to reinforce exclusive territorial governance. Supranational agencies of governance, such as the EU, are limited to specific functions and are legitimated and underwritten by modern territorial states. They tend, however, to become new territorially defined entities. In fact, the EU's drive to re-territorialise is not a mere academic question: it has very real consequences for our lives and for peoples, places, States, regions, and especially for those beyond the border. 
This process of European "re-territorialisation" may hinder the processes of both interaction and cooperation across the EU's external borders and stimulates many problems and political difficulties. By strengthening its external borders, the EU protects its own economic and political space, but it also isolates itself further from the rest of the world.

\section{EU's "new territoriality"}

In fact, the notion of territoriality and the prevalent "territorial" discourse produced an evident eclipse of the widespread notion of "European space" that had been developed in the early 1990s. This process is probably an inevitable consequence of the same EU's concepts of enlargement and political integration, based on a sharp system of inclusion and exclusion, defined by full membership status. In recent years have appeared even the European spatial policy concepts of "territorial cohesion", "territorial governance" and "territorial development policy". Basically, the EU's spatial predominant conception contributes to an emergence of a sharpened territorial building of the European space. But the EU as a political space is territorially ambiguous. Regulatory decrees are trans-European. Membership is nation-state based. Be that as it may, the European Union is currently undergoing a process of sharpening its territorial profile, which manifests itself in different ways, especially in its external dimension. Several developments in the European Union after the first enlargement, such as the widening of the Schengen area ${ }^{1}$, the Lisbon Treaty $^{2}$, and the Frontex agency show that the territorial concept, in a modern geographical sense, is still influent and seems to evolve towards a polity with "Westphalian" characteristics. Most of the member states wanted to move the Community towards a closer economic and political union. "Internal cohesion" became one of the pillar of the Community structure (Fitzgerald and Michie 1997, p. 20). But the security discourse still prevails over the economic integrationist discourse that dominated European politics till the last enlargement round and within that discourse there is a tension between "security through inclusion" and "through exclusion". According to David Newman (Newman 2006, p. 88), "re-territorialization" offers a mean of interpreting the EU's structure. In fact,

${ }^{1}$ The new focus on the controlling of the EU's external borders was also triggered by the Schengen Treaties (Albrecht 2002, p. 1).

${ }^{2}$ The contemporary tendency towards an Europe with a Constitution, President, Minister of Foreign Affairs and above all a clearly demarcated territory with a sharp inside/ outside dichotomy, borders as barriers, is going on. It represents a project of a very restricted and closed EU (cf. Boedeltje, van Houtum 2008, p. 361). Control of the EU's external borders and the struggle against irregular immigration occupies a prominent position in the Hague's Programme's goal of «Strengthening freedom, security and justice in the EU» which was ratified by the European Council in 2004. 
"re-territorialization" involves both a process through which "territorial configuration of power are continually ordered and reordered as well as a continuous practice of differentiating and defining borders between societies according to specific criteria and bordering is, by nature, a multilevel process of "re-territorialization". The EU as an expanding political project is actively engaging in processes of bordering. The consolidation of the EU has underpinned dramatic transformations of political space. At the same time, while "postnationalism" would lead to a recognition of pluralism at the basis for European belonging, the "supranational" approach taken in the construction of a unified European space mimics de facto the structure of the modern nation-state. The borders within Europe change but overall are strengthened or made increasing impermeable. The prevailing discourse about the European spatial development is increasingly littered with references to territory, territoriality and territorial cohesion in terms of social (the European Welfare), political, cultural and mental spaces united in a unified physical space. The spatial dimension manifests itself most clearly in the drawing of territorial boundaries that separate the inside from the outside. Already in the Constitution's provisions (Treaty Establishing a Constitution for Europe 2005) the themes of territoriality and territorial cohesion recur again and again. The cohesion of its territory is explicitly posited as codified and institutionalised, something to be reinforced (Burgess 2009, p. 148) 3 $^{3}$ Nowadays the European Commission conceptualizes the EU as a demarcated area with a clear inside and outside, surrounded by a "ring of friends" (European Commission 2003) ${ }^{4}$. The contemporary dominant discourse and metaphors on the EU's political geographical nature are still clearly territorial. Despite the fact that at the beginning of the European Project the aim was to incorporate as many states and people as possible than to create a restrictive union, the EU is still based on the concept of contiguous territories, territorial integrity and it needs a clear understanding of what belongs and what does not belong to the Union. The creation of a single space triggered a wish to demarcate and border the European political space and entity (Islam 1994, p. 38). Especially the external border is a clear dividing line between "them" and "us" and defines which territory is European and which is not European. A new common external border became needed to protect the entire Union (Harvey 2000; Geddes 2001) and the external border have been increasingly policed (Albrecht 2002), representing a clear conception of hard territoriality, despite its full implementation. Concerns about the safety of the Union rose quickly in the 1990's. The abolition

\footnotetext{
${ }^{3}$ Among the objectives formulated in Title 1 is the promotion of economic, social and territorial cohesion (Burgess 2009, p. 148; Treaty Establishing a Constitution for Europe 2005, p. 17).

${ }^{4}$ This document refers to the European territory as a clearly demarcated space, and uses the definitions "Within and beyond the new borders of the Union" and the concept "Ring of friends".
} 
of the internal border controls created a perceived need for enhancing the barrier functions at the external EU's border (O'Dowd 2002, p. 21). The EU is now a territorial structure with policing of its physical external borders, walls, hardware, and internal surveillance of the territory, strong immigration laws, and a protectionist policy, especially in areas like agriculture. Membership of and belonging to the EU automatically creates exclusion, and it is necessary to remember that the right to control and deny admission of foreigners is often seen as crucial to a nation state's sovereignty and territorial integrity (Leitner 1995, p. 261). As wrote Colin Harvey, "supranationalism" requires a process of boundary drawing

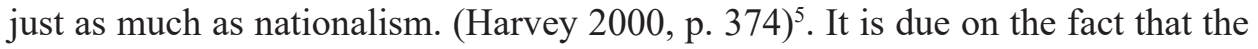
supranational approach taken in the construction of a unified European space mimics the nation-state, re-territorializing the European space within a framework of territorial states. As a result, remapping a political community "supranationalism" is not antithetical to the Westphalian concept of modern territoriality (as the federal approach): it contains all the main concepts of jus publicum europaeum, including a hierarchical idea of levels of government, with competencies (foreign policy, migration and trade policy, transborder cooperation and so on) shifted from national state to EU-level (including sovereignty, which is antithetical to federal paradigm) and the borders in modern sense. The paradox of supranationalism lies in the fact that while questioning the nation-state, it also reinforces the role of the state in the building of a political Europe. EU's space has become the projection of the nation-state onto a transnational scale. The empirical evidence suggests that states remain the driving force of the EU. It is not surprising that the demarcation, bordering and securing of the common European space became the permanent conception of scholars, politicians and of the media. Bordering is driven mostly by fear of crime and the need to be amongst "ourselves", hence protecting welfare, security and identity (Van Houtum and Pijpers 2007, p. 303). The EU aspires to become an international actor by extending its institutional power and superimposing its borders on the already existing state borders of European nation-states. Even though some scholar claim external borders of EU as "undefined external boundaries" (Wallace 1999, p. 519), these borders maintain a clear function of barrier.

The modern characteristics of EU's external border appear by the attempt to sharply separate between internal "law and order" of the internal space (Innenraum) and the outside dimension to which expel all the impossible to assimilate "disorder". This is the typical logic of the modern state: the production of the "order" inside the borders and the expulsion of the "disorder" outside. The EU's borders are evidently still characterized by a "Westphalian memory" in the way to use

${ }^{5}$ Harvey adds that a boundary between "us" and "them" and the construction of the mechanism to ensure inclusion cannot be wished away, because it is the consequence of the ambitious aims of the EU (Harvey 2000, p. 374). 
the territory as support of political unity (Badie 1995; Reut 2000) and correspond to the modern idea of "political territorial exclusivity" (sovereignty) ${ }^{6}$. For many years Bruxelles pretended that candidate states transformed their borders into a more rigid barrier: otherwise the political 'centre' did not let them to enter in an Union based on a precise and continue territory (as it happened to Poland). This territorial concept de facto caused through the years an "involution" of the border and rendered the borders impermeable and certainly not "fuzzy frontiers zone". This process reflected the same conception of the creation (already existing in the Cold War period) of a big self-sufficient, autarchic area, closed by a customary and boundary belt, which remembers the ideal of the 'Fichtean' geschlossene Handelsstaat, a territorial closed and mercantilist area.

Although the EU's territoriality is still less fixed and less exclusive than that of modern states and progresses in a complex, multifaceted, and non-linear fashion, the "supra-national" character of the EU (which means permanence of the nations or nation states) is not enough to make different that kind of potential unification among states, founded in Maastricht, from other unifications that used modern borders as an instrument of building of state territory. The EU is acknowledged to be a political hybrid which eludes conventional categories of national or international political organization but regarding the external dimension of European territorialisation it is becoming an actor involved in spatial ordering within and outside its territory. Of fundamental importance is the fact that the EU continues to display its greatest institutional strength along the territorial lines of its member states. The hardening of borders in the name of security acts to reinforce the division between "insiders" and "outsiders". It corresponds to an old form of territorialisation of politics and to the building of "internal" and "external" dimensions at the EU's borders.

\section{Europe in the Middle Ages: a totally different continent}

Before the sixteenth century neither the sovereign territorial state (with his typical spatial feature) nor a system of international politics based primarily upon such states existed. Before the European state building, there was no clear distinction between domestic politics and international sphere. Europeans have for many centuries moved freely over each other's lands, contributing their distinctive patterns to the cultures of different countries. Europe has always been "transnational", especially in multinational empires that occupied much of its space until the nineteenth century (Lieven 2001). The space of empire created permeable and fluid boundaries that allowed for a considerable mingling of peoples, including those of non-European origin. Medieval empires, generally speaking, had no proper

${ }^{6}$ «The Westphalian model of international political life presumes a notion of hard borders» (Mostov 2008, p. 20). 
borders in the modern sense of fixed and clear boundaries. It depended on the weakness of sovereignty as concept and practice ${ }^{7}$. Within empires (particularly Austrian and the Holy Roman Empire) there was a plethora of political constitutions, privileges, overlapping authorities, immunities, traditions and customs. Moreover, there have been many cultural groups who have made major contributions to the cultures of European lands. The Jews are one example, considering Central and Eastern Europe. Muslims are another, in the form of Arabs in Spain and in Sicily. And what about Mongols in Russia, or Turks in the Balkans? European culture would have been immeasurably different, not to say infinitely poorer, without them. Europe has an intrinsic historical openness and cannot be understood with a definite beginning or end. As it is well known, the Mediterranean once was a bridge of civilizations between Europe, Africa and Asia. Only after discoveries of XVI century it became a European periphery and only in XX century a border zone. Similarly, EU's Eastern border replies that of iron curtain, even if it is located on a more eastern, new line, only partially reproducing that of former Polish-Lithuanian Confederation. For centuries Eastern European countries had loose border areas and marches rather than sealed type of borders.

Medieval Europe, as is well known, was a society made up of different and plural political entities entering into complex (mainly contractual) mutual relations. Up to the advent of the modern State, "the international community" had been dominated by the contract. In fact, political relations were contractual: the medieval Latin vocabulary did not contain political terms and only those of private law related to private relations. Politics was conducted by private means of tribunals and acted through law. Only subsequently the two entities split, paving the way for the modern State which politicized everything. Only later did the political lexicon come into use and bring about the transformation of the community. But before this process, there was thus no clear distinction between domestic politics and international relations. Medieval politics was marked by multiplicity of authorities based on different lands. A glance on the map of XIII-XVI centuries would reveal immense fragmentation: a mosaic of duchies, bishoprics, free cities, leagues and confederations of cities, principalities and kingdoms. This fragmentation was a product of feudalism: an unfortunate and eclectic term ${ }^{8}$ but at the same time a word related to specific relationships of political authority and (only later) a complex of rights over land: particularly in France, that had been for a long time

${ }^{7}$ Even after the Westphalian Peace Treaties of 1648 ius territorialis was not the same as sovereignty (the concept theorized by Bodin and Hobbes) over a territory. Manifestly, the governance structure of this conglomerate of political units was complex, conflictual, and contested (Axtmann 2003, p. 137).

${ }^{8}$ See F. Oakley (1993, p. 115). 
territorially highly fragmented ${ }^{9}$. The notion of firm boundary lines between the major territorial formations did not take hold until the thirteenth century; prior to that date, there were only frontiers or large zones of transition. Across Europe boundaries were porous and ill-defined. Kings and leading nobles continuously disputed one another's right to territory and also inherited lands within the space of another kingdom.

Historical regions born in medieval Europe, with its patchwork of overlapping and incomplete rights of very different forms of authorities (Strayer, Munro 1959, p. 115; Strayer 1970), which were inextricably superimposed and tangled, and in which different juridical instances were geographically interwoven and stratified, and plural allegiances, asymmetrical suzerainties and anomalous enclaves abounded (Ruggie 1993, p. 150). Before the nation-state structure, prevailed a nonexclusive form of territoriality, with many forms of personalized and fragmented authorities within and across territorial formations, with inclusive bases of legitimization.

The main change in the political structure of Europe was the creation and the spread of firm territorial boundary lines between political formations. The most distinct feature of modernity in international politics came to be a particular form of territorially-disjoint, fixed, and mutually exclusive - as the basis for organizing political life. Historical regions, mostly spontaneous, were forced to adopt these lines and a specific form of "spatial extension" of the states, strongly connected to an inclusive base of legitimization, mutual exclusion and to a gradual differentiation between internal and external, as "natural" and inevitable. In fact, this process was unique in human history (Sack 1986). As a result, the model of nation-state increasingly opposed the particularism articulated in language, culture, cults, life-styles and customs that constitute a people's concrete social texture and the basis for specific political institutions reflecting a local character. States were built around the idea of territorial homogeneity and unity.

As Hendrik Spruyt explained, historical regions, the Hanse or Italian city-states in fact were viable political alternatives to the territorially defined, territorially fixed, and mutually exclusive states (Spruyt 1994). The nonterritorial Hansa resembled the imperial form of organization. But strong centralized administration and socially legitimate power (by its subjects) have completely transformed the political life of Western and Central Europe (Johnson, Percy 1970, p. 56), even if, as Charles Tilly pointed out, the leaders of prior institutions and even ordinary

\footnotetext{
${ }^{9}$ On the contrary - this is quite curious - in Britain the first principle after the Norman conquest was that “All land belongs to the king”. See F. Maitland (1908, p. 155), E. Jenks (1919, p. 35). As a result, in Britain, because of the strong power of the king, feudalism tended to produce centralization since the very beginning rather than fragmentation (Van Caenegem 1995, p. 53).
} 
people fought the claims of central states for centuries, right into the $17^{\text {th }}$ century (Tilly 1975, p. 22). But territorial rulers recognized to be irreducibly "transterritorial" in character (as during the medieval period) only few regional units, considering these formations as relicts.

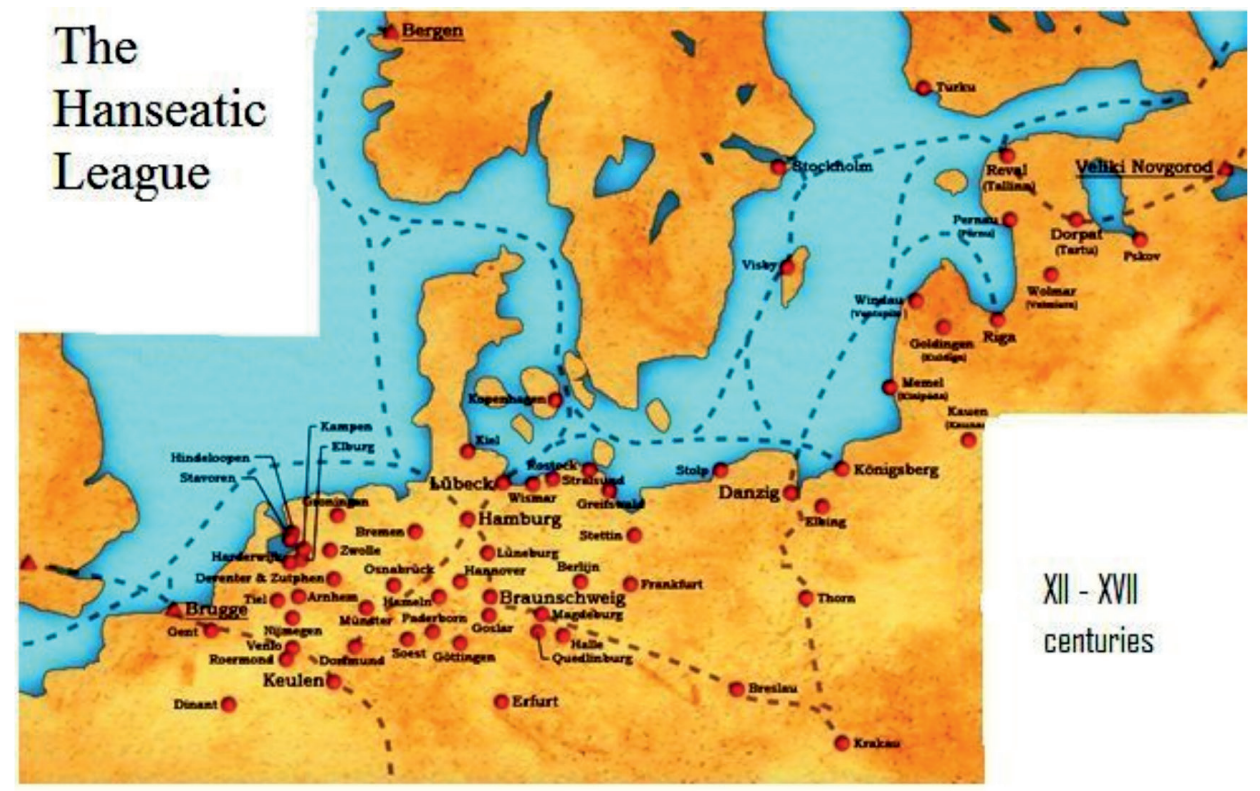

Fig. 1. The Hanseatic league (XII-XVII centuries)

Source: author's own elaboration

Ruling powers competed to control the same spaces, claiming forms of territorially and functionally specific rule that were ill both in scope and rights. Subjects owed different obligations to different rulers. Medieval Europe was thus a complex political and social system created by a world of overlapping and competing governing powers of different types. In the 1570s France resembled the Lebanon in the mid-1970s and remained a patchwork of competing local powers up to the Revolution (Hirst 2001, p. 48, 50). The Hanseatic League was a prime contender to be a rival form of large-scale political organization to the territorial state and its spatial conception.

Only after the crystallization of the new international system and the emergence of the sovereign territorial state as the dominant form of political organization (with a definite territory and boundaries at its exterior, an exclusive control of that territory, an internal hierarchy and so on) the physiognomy of Europe radically changed. At the beginning of $19^{\text {th }}$ century Fichte theorized the birth of the nation-state as an entity closed even from an economic viewpoint. Outside the borders 
there are enemies and disorder. Enemies have to be thought and disorder needs to be dealt not through contractual relations but by means of power: by Machtpolitik. Since the late eighteenth century Europe has also been national to an increasing extent. It has come to be defined by nation-state. This process culminated in the post-WWII bipolar system that subsumed all political syntheses. Bipolarity brought about the maximum level of politicization through hierarchization. Indeed, the tensions between the two superpowers kept the community of states in line and well ordered. There was no other choice. All controversies were regulated through this kind of opposition.

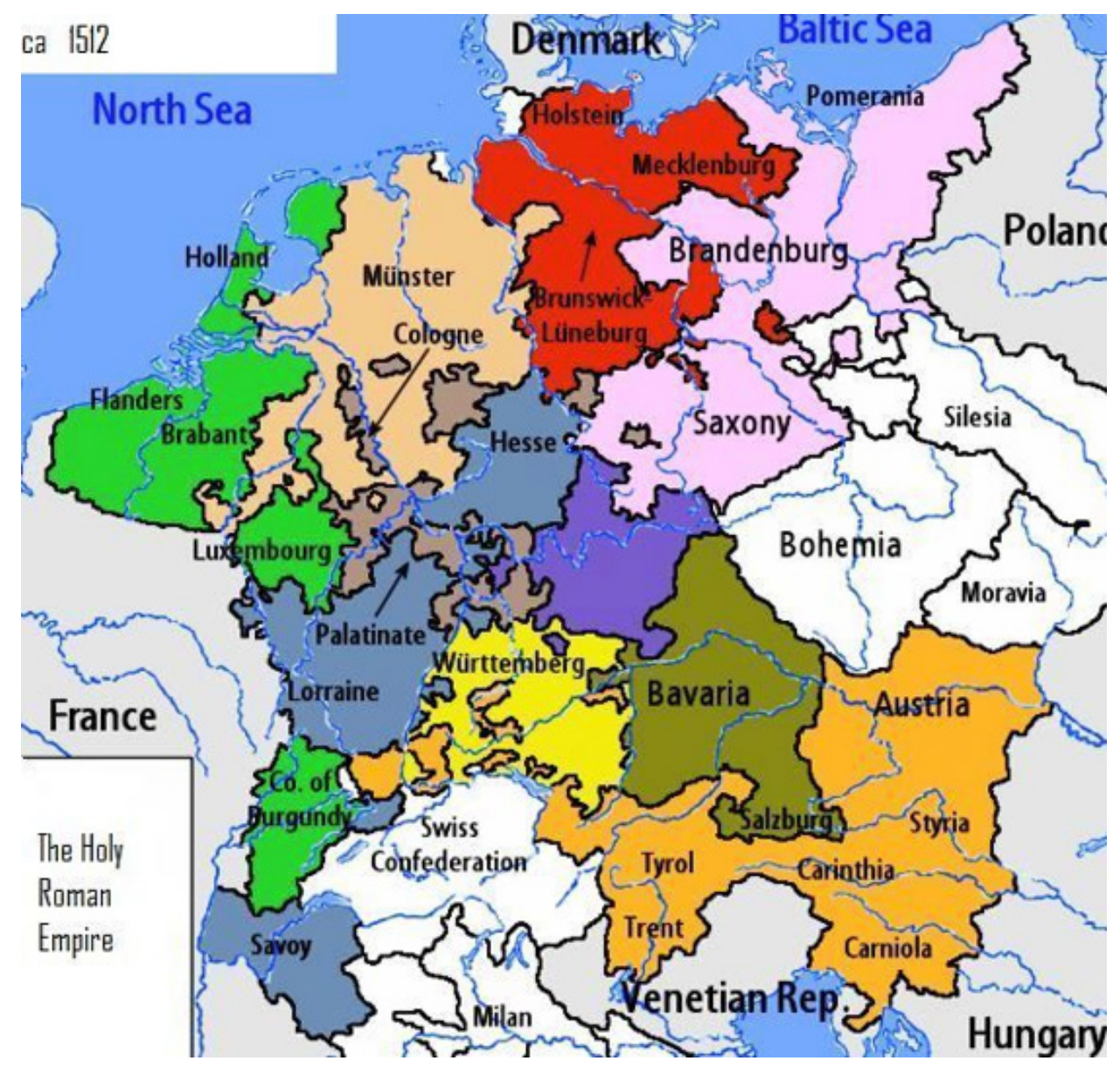

Fig. 2. The Holy Roman Empire (c. 1512)

Source: author's own elaboration 


\section{A new challenge after the end of bipolarism}

It is necessary to keep in mind that EU is a product and a legacy of the cold war. The bipolar world divided Europe into East and West, a divide fortified until recently by the European Community and the European Union is a de facto Western European Club. But with the end of this international system international community has returned to a form of situation prior to modernity. There is no room for an international authority, for the expansion of the UN's role, for the consolidation of a continental coherent political unit that functions according to the principle superiorem non recognoscitur. But the EU preserves in his genetic patrimony a project depending on bipolar world. The territorial prerequisite of the EU and the prevalent idea of borders is a mirror of the bipolar origin of this "new Europe". In the academic debate on the future of the EU reference has been made to the experience of the Holy Roman Empire (Schmitter 2000). Some commentators have seen the Hanseatic League as a model that may be useful as a way to thinking about the European Union (e.g. Pichierri 1997). Actually, in many ways the League looks like a surprisingly modern organization echoing forms of supranational governance today. But at that time there was a plurality of political subjects very different in form, substances and objectives: the Empire, the Church and small, totally unrealized sovereignties. The key cities of the League were connected by a set of common institutions and procedures for decision making. The League signed treaties with monarchs, obtained extraterritorial privileges for its trading, and used armed forces very rarely to enforce its collective will. It was a quasi-polity with common but functionally very limited institutions, whose members were self-governing entities in their own right. It depended on a small number of its leading cities. It operated on a European scale. The "supraterritoriality" and non-centralized/non-territoriality of the League (of medieval kind) became a disadvantage the more the principle of territorial sovereignty took hold. The League's fundamental principle of governance relied on an European political system that was not territorially exclusive, in which political as well as trade links could be forged between cities within and outside the nominal sovereignty of Empire (Hirst 2001, p. 52). Also the Holy Roman Empire did not define itself by control over a given territory; it lacked, as the Hanseatic League, territorial fixity and exclusivity (Spruyt 1994, p. 51): so it may serve as an analytical, but sure not as a description of the contemporary EU's political space. Before exclusive territoriality took hold the forms of political identification we take to be normal did not exist. The project of building identification on the part of peoples, political legitimacy and territorial powers are strong related in European history. On the contrary, loyalties at that time could be divided, just as sovereignty was 
parcellized. Medieval Europe could have no clear distinction between domestic and foreign politics, and thus nothing resembling a proper international system characterized by the centralization of sovereign power and jus publicum europaeum as products of an accelerating process of interstate conflict that begins in the early sixteenth century. The new war system was structured by two basic principles, both of which favoured the sovereign territorial state (Spruyt 1994): the first principle is territorial exclusion and the second constitutive principle of the new international system is mutual recognition. According to the former, all entities that are not coherently territorial and exclusively sovereign within are progressively delegitimized and expelled from the international system. The chief victims were those political bodies that had been parts of the old Christian Commonwealth of Europe along with the monarchs and princes. Thus the Church as a dominant European institution in the Respublica christiana, the monastic military orders, the Hanseatic League and the city-state were all either eliminated or marginalized as international players in the course of the $17^{\text {th }}$ century. Indeed, both the League and the Papacy had no part in the peace process of Westphalia. The Holy Roman Empire, the other prime loser with the Papacy in 1648, was reduced by the outcome of the Thirty Years' War to a hollow political shell in which the various German states became to enjoy a degree of sovereignty just short of complete independence. Following the latter, legitimate membership of the system depended on acceptance by others states as the exclusive ruler of a definite territory. A defining feature of modern sovereignty is the recognition by states of the difference between internal and external policy. Many of the features of the old European order persisted for some time after Westphalia. However this turning point is central in initiating the territorialization of politics and economy. The other aspect of seventeenth-century state-building in Europe is the discovery of the economy by political classes. The creation of exclusively governed distinct territories had been a precondition for the notion of a "national economy". The result was the widespread adoption of mercantilist doctrines and practices. This consequence continued in the Fichtean ideal of the geschlossene Handelsstaat and in the EU's conception of territoriality. Common to all scenarios of the new Europe is the relative decline of the state and the partial decoupling of power and territory.

Today it is necessary to assume a dynamic approach toward relations between political subjects, to consider them transitory and tied to a limited temporality both in international relations and in the constitutions. One can rediscover the role of the enclave. It is possible to rethink territorial borders and ties outside territorial spatial contiguity in order to solve many contemporary problems (Mostov 2008) but only abandoning old concepts. 


\section{Conclusions}

A new agenda in historical scholarship has emerged which emphasises institutions that facilitate interaction across state borders, be they of commerce, communication or government. This is to place the focus on the means, the content and the consequences of a whole range of connections that transcend politically bounded territories and connect various parts of the world to one another. Its ambition is to undermine political claims to hegemonic and foundational status and highlight the permeability of states and nations, making visible a wider range of political possibilities. The comprehension of the transnational dimension opens new avenues of research and offers new modes of understanding. It must nonetheless be pointed out that history is written through the prism of the state.

This conception is related to the popular conviction that the "EU/Europe" has always been a fixed territory and that some European countries cannot belong to it. The Treaty of Lisbon also made a step forward to the creation of a territorial polity at the European level (Marcinkowska 2011, p. 70-79) using a clear rebordering strategy which aims to reassert state borders (perceived as ineffectual) and make them more difficult to cross at the external line of the Union. In fact, the contemporary EU's concept of territoriality contains characteristics of a "neoWestphalian" model. It is self-contradictory and highly problematic arguing that the EU is a polity that evolves towards a weak empire or a "maze Europe" with soft and flux external borders of "fuzzy" nature, as e.g. wrote Zielonka (Zielonka 2006 , p. 6,144 ) or to say that the inside/outside division is blurred because the EU's authority does not stop at its own external borders (Böröcz 2001, p. 18-19). External borders and inside/outside dichotomy show the reality of the predominant conception of the EU that is based on the Westphalian clear-cut borders as well defined lines as an ideal that need to be implemented.

"Post-national" or "post-modern" borders are not replacing classical nation-state borders at European level. The increasing transnational flows of capital, products, services, labour and information have generated a growing need for border-crossing mechanisms. The rising of pressures towards the development of continuous spontaneous cross-border contacts confirms the existence of a push toward the recovery of optimal dimensions of cooperation, above all on the economic plan. But the empirical evidence suggests that states remain the driving force of the EU and it became quite clear that the permanence of the nation-State as a model for a political unit in the construction of Europe is the same basis of EU. The firewall metaphor (an asymmetric membrane) explains nicely the EU's bordering dilemmas: people seek access to and engagement with the wider world of globalization but are apprehensive of doing so. This membrane allows some sort of freedom of movement and commerce but the aim is to find at the same time protection forming a barrier to those whose presence is undesirable and who 
remain shut out by EU's securitized boundaries. In line with state-centric thinking, border-related strategies remain a powerful tool in the hands of EU's member states that are encouraged to be in charge of their borders. Moreover, there are increasing demands within the EU to put an end to enlargement and to demarcate where the "final European borders" are. This clearly shows the continued relevance of the state-centric approach, in which borders circumscribe territory and shape the identity of the political community (Dimitrova 2010). The possibility to escape the inside/outside dichotomy clashes with the state-centric paradigm and the urgency to protect and safeguard the Union's citizens that has predominated the discourse on bordering. On the contrary, the imperial analogy implies a variable permeability and softening of borders that opens up relevant alternatives.

\section{LITERATURE}

Albrecht H., 2002, Fortress Europe? - Controlling Illegal Immigration, „European Journal of Crime, Criminal Law and Criminal Justice", 10(1), s. 1-22.

Anderson J., 1996, The Shifting Stage of Politics: New Medieval and Post-modern Territorialities?, „Environmental Planning”, 14(2), s. 133-153.

Anderson J., 2007, Singular Europe: an Empire once again?, [w:] Armstrong W., Anderson J. (red.), Geopolitics of the European Union Enlargement: the Fortress Empire, Routledge, London.

Axtmann R., 2003, State Formation and Supranationalism in Europe. The Case of the Holy Roman Empire of the German Nation, [w:] Berezin M., Schain M., Europe Without Borders. Remapping Territory, Citizenship, and Identity in a Transnational Age, The Johns Hopkins University Press, Baltimore \& London.

Badie B., 1995, La fin des territoires. Essai sur e désordre international et sur l'utilité sociale du respect, Fayard, Paris.

Boedeltje F., Van Houtum H., 2008, The abduction of Europe: a plea for less Unionism and more Europe, „Tijdschrift voor Economische en Sociale Geografie”, 99(3), s. 361-365.

Böröcz J., 2001, Introduction: Empire and Coloniality in the 'Eastern Enlargement' of the European Union, [w:] Böröcz J., Kovacs M. (red.), Empire's New Clothes. Unveiling EU Enlargement, e-book: Central European Review online.

Burgess P.J., 2009, The New Nomos for Europe, „Geopolitics”, 14(1) (July), s. 135-160.

Dimitrova B., 2010, Remaking Europe's Borders through the European Neighbourhood Policy, Center for European Policy Studies, CEPS Working Document No. 327 (www. ceps.eu).

European Commission, 2003, March 11, Wider Europe - Neighbourhood: a new Framework for Relations with our Southern and Eastern Neighbours, Communication from the Commission to the Council and the Parliament - Brussels.

Fitzgerald R., Michie R., 1997, The Evolution of the Structural Funds, [w:] Bachtler J., Turok I., The Coherence of EU Regional Policy. Contrasting Perspectives on the Structural Funds, Jessica Kingsley Publishers, London. 
Geddes A., 2001, International migration and state sovereignty in an integrating Europe, „International Migration”, 39 (6), s. 21-42.

Harvey C., 2000, Dissident voices: refuges, human rights and asylum in Europe, „Social and Legal Studies", 9(3), s. 367-396.

Hirst P., 2001, War and Power in the $21^{\text {st }}$ Century, Blackwell Publishers, Malden MA.

Islam S., 1994, Fortress Europe, „Index on Censorship”, 23 (3), s. 37-43.

Jenks E., 1919, Law and Politics in the Middle Ages, Murray, London.

Johnson J., Percy W., 1970, The Age of Recovery: The Fifteenth Century, Cornell University Press, Ithaca.

Leitner H., 1995, International migration and the politics of admission and exclusion in postwar Europe, „Political Geography”, 14(3), s. 259-278.

Lieven D., 2001, Empire. The Russian Empire and its Rivals, Yale University Press, New Haven CT.

Maitland F., 1908, The Constitutional History of England, Cambridge University Press, Cambridge.

Marcinkowska P., 2011, Europejska Polityka Sasiedztwa. Unia Europejska i jej sąsiedziwzajemne relacje $i$ wyzwania, Wydawnictwo Uniwersytetu Warszawskiego, Warszawa.

Mostov J., 2008, Soft Borders. Rethinking Sovereignty and Democracy, Palgrave Macmillan, New York.

Newman D., 2006, The Resilience of Territorial Conflict in an Era of Globalization, [w:] Kahler M., Walter B. (red.), Territoriality and Conflict in an Era of Globalization, Cambridge University Press.

Oakley F., 1993, The Medieval Experience, Toronto University Press, Toronto.

O'Dowd L., 2002, The Changing Significance of European Borders, „Regional and Federal Studies", 12 (4), s. 13-36.

Passerini L., 2002, From the Ironies of Identity to the Identities of Irony, [w:]: Pagden A. (red.), The Idea of Europe: from Antiquity to the European Union, Cambridge UP, Cambridge.

Pichierri A., 1997, Città stato. Economia e politica del modello anseatico, Marsilio, Venice. Preuss U.K., 1998, Citizenship in the European Union, [w:]: Archibugi D., Held D., Köhler M. (red.), Re-imagining the Political Community, Stanford University Press, Stanford CA.

Reut O., 2000, Republic of Karelia: A Double Asimmetry or North-Eastern Dimensionalism, Copenhagen, COPRI Working Paper 13, Peace Research Institute, Copenhagen.

Ruggie J.G., 1993, Territoriality and Beyond. Problematizing Modernity in International Relations, „International Organization”, 47 (1) (Winter), s. 139-174.

Sack R.D., 1986, Human Territoriality. Its Theory and History, Cambridge University Press, New York.

Schmitter Ph.C., 2000, How to Democratize European Union ... and Why Bother?, Roman and Littlefield, New York.

Spruyt H., 1994, The Sovereign State and Its Competitors, Princeton University Press, Princeton NJ.

Strayer J.R., 1970, On the Medieval Origins of the Modem State, Princeton University Press, Princeton NJ. 
Strayer J.R., Munro D.C., 1959, The Middle Ages, Appleton-Century-Crofts, New York. Tilly C., 1975, Reflections on the History of European State-making, [w:] Tilly C. (red.), The Formation of National States in Western Europe, Princeton University Press, Princeton NJ.

Treaty Establishing a Consitution for Europe, 2005, Office for Official Publications of the European Commission, Luxembourg.

Van Caenegem R.C., 1995, An Historical Introduction to Western Constitutional Law, Cambridge University Press, Cambridge.

Van Houtum, H., Pijpers R., 2007, The European Union as a Gated Community: The Two-faced Border and Immigration Regime of the EU, „Antipode”, 39 (2), s. 291-309.

Vitale A., 2011, The Contemporary EU's Notion of Territoriality and External Borders, „European Spatial Research and Policy”, 18(2), s. 17-27.

Wallace W., 1999, The Sharing of Sovereignty: the European Paradox, „Political Studies”, 48.

Zielonka J., 2006, Europe as Empire: the Nature of the Enlarged European Union, Oxford University Press, New York.

\section{MITY TERYTORIUM I GRANIC ZEWNETRZNYCH W UNII EUROPEJSKIEJ I ŚREDNIOWIECZNEJ EUROPIE}

\section{Zarys treści}

Dyskurs nad polityką zagospodarowania przestrzennego w Unii Europejskiej nabrał ostatnio charakteru „terytorialnego”, zwłaszcza po kryzysie migracyjnym. Mimo, iż terminologia dotycząca tej dziedziny polityki bywa niejednoznaczna, to pojęcia terytorium oraz terytorialności są de facto coraz bardziej powszechne w dyskursie nad organizacją przestrzeni europejskiej (czyli UE). W rzeczywistości pojęcie terytorialności wyraźnie przyćmiło powszechne pojęcie ,,przestrzeni europejskiej", które zostało opracowane na początku lat 90. ubiegłego stulecia. Zasadniczo dominująca koncepcja przestrzenna UE przyczynia się do zaostrzenia budowy terytorialnej przestrzeni europejskiej. Zarówno idea spójności terytorialnej, jak i ciągłości terytorialnej zapewnia odpowiedni wgląd w pojęcie terytorialności w ramach „dyskursu europejskiego", a co za tym idzie wyraźnie pokazuje stopień akceptacji narzędzi rozgraniczających (w ramach polityki i praktyki), a także ostrą dychotomię wewnętrzną/zewnętrzną oraz wykorzystanie terytorium jako elementu wsparcia dla zunifikowanej jednostki politycznej. W związku z tym pragmatycznym pojęciem terytorialności, wizja Unii Europejskiej jako „nowego imperium”, charakteryzującego się zmiękczeniem granic i podziałem władzy politycznej pomiędzy wieloma wielopoziomowymi politykami, stała się co najmniej nierealna. Z drugiej strony Europa zawsze wyróżniała się otwartością na pozostałą część świata. Nigdy też nie była wyraźnie odgraniczonym kontynentem lub wydzieloną stałą granicą całością i zawsze charakteryzowała się przesunięciami przestrzeni politycznych. Średniowiecze w Europie charakteryzowało się nachodzeniem na siebie podzielonych 
struktur władzy i często kontrowersyjnych jurysdykcji, bez obudowy terytorialnej i jasnego pojęcia granicy. Dostrzeżenie wymiaru ponadnarodowego otwiera nowe możliwości badawcze i oferuje nowe sposoby pojmowania problemu.

Słowa kluczowe Granice, Unia Europejska, spójność terytorialna, średniowiecze.

Alessandro Vitale, Assistant Professor

Department of International Studies

University of Milan, Italy 